\title{
PERTUMBUHAN DAN PERKEMBANGAN GONAD EMPAT STOK IKAN BAUNG (Mystus nemurus) GENERASI PERTAMA
}

\begin{abstract}
Ningrum Suhenda*), Rusmaedi*), dan Atmadja Hardjamulia*)
ABSTRAK

Penelitian ini merupakan penelitian lanjutan tahun 1999 dan bertujuan untuk mengetahui pertumbuhan dan perkembangan gonad empat stok ikan baung (Mystus remurus) generasi pertama. Penelitian dilakukan di keramba jaring apung (KJA), berukuran $2 \times 2 \times 3 \mathrm{~m}^{3}$ di Waduk Cirata. Setiap stok ikan baung dipelihara di tiga buah KJA, kecuali untuk stok Wadaslintang. Padat penebaran 40 ekor/KJA dengan jumlah jantan dan betina masing-masing 15 dan 25 ekor. Ikan diberi pakan berupa pelet komersial dengan kadar protein $30 \%$, dan ransum harian $3 \%$ bobot badan. Pertumbuhan dan perkembangan gonad dianalisis secara deskriptif. Hasil penelitian menunjukkan bahwa pertumbuhan ikan jantan lebih cepat $(11,65 \%-15,97 \%)$ dari ikan betina untuk seluruh stok ikan. Pertumbuhan ikan baung stok Wadaslintang dan Jatiluhur lebih cepat daripada stok lainnya. Ikan betina sudah dapat matang kelamin pada umur 16 bulan dengan bobot antara $251-320 \mathrm{~g}$. Jumlah tertinggi induk betina yang matang gonad didapatkan pada stok Jatiluhur sebesar 94,54\% pada bulan Februari 2001.

ABSTRACT: Growth and gonad development of the first generation of four stocks of green catfish (Mystus nemurus). By: Ningrum Suhenda, Rusmaedi, and Atmadja Hardjamulia

The objective of the study (as the continuation of 1999 observation) was to evaluate growth rate and gonad development of the first generation of four stocks of green catfish (Mystus nernurus). The experiment was conducted in floating net cages of $\left(2 \times 2 \times 3 \mathrm{~m}^{3}\right)$ in Cirata Reservoir. Each stock was reared in three floating net cages, except for Wadaslintang stock which was only in one cage. The stocking density was 40 fish per cage, consisted of 15 males and 25 female. Pelleted comercial feed $(30 \%$ protein) with a daily ratio of $3 \%$ of body weight was given three times daily. The result showed that growth of male was faster $(11.65 \%-15.97 \%)$ than female. Growth of Wadaslintang and Jatiluhur stocks were faster than the other two. Female started maturing at the age of 16 months with body weight between 251-320 g. The highest number of mature female (94.5\%) was found on Jatiluhur stock in February 2001.
\end{abstract}

KEYWORDS: green catfish, floating net cage, growth, gonad development

\section{PENDAHULUAN}

Ikan baung (Mystus nemurus) merupakan ikan perairan umum dengan penyebaran yang relatif́luas di Pulau Jawa, Sumatera, dan Kalimantan (Robert, 1989). Jenis ikan ini digemari masyarakat, dan mempunyai arti penting khususnya di Sumatera, seperti di Jambi (Nasution et al., 1993) dan di Riau (Sukendi, 2001). Di Jawa Barat, jenis ikan ini digemari masyarakat dan mempunyai harga lebih tinggi daripada harga ikan mas.

Penelitian jenis ikan ini telah banyak dilakukan mulai dari sumber dayanya di alam (Alawi et al., 1992; Samuel et al., 1995; Sukendi, 2001), pembenihannya (Gaffar \& Muflikhah, 1992; Muflikhah et al., 1993; Hardjamulia \& Suhenda, 2000; Sukendi, 2001) sampai kepada pembesarannya (Muflikhah \& Gaffar, 1992; Muflikhah \& Aida, 1996). Di Thailand, penelitian larva sejenis baung telah dilakukan pula (Amornsakun,
1999; 2000). Hal yang menarik dari hasil penelitian tahun 1999 adalah ikan baung yang dipelihara di keramba jaring apung (KJA) dapat matang kelamin dengan pemberian pakan buatan berupa pelet dengan kadar protein sekitar $30 \%$. Selain itu, ikan baung menghasilkan telur dengan diameter yang relatif besar, sehingga pertumbuhan larvanya relatif cepat dan dapat lebih cepat mengkonsumsi cacing tubifex (Hardjamulia \& Suhenda, 2000).

Penyebaran ikan baung yang luas di Indonesia memberikan kemungkinan adanya plasma nutfah yang berbeda yang mempunyai karakteristik dan sifat biologi yang berbeda pula dan diharapkan di antaranya terdapat sifat pertumbuhan yang lebih baik atau sifat reproduksinya lebih produktif. Pada penelitian sifat reproduksi pada keempat stok ikan yang berasal dari Cirata, Jatiluhur, Wadaslintang, dan Wonogiri telah diperoleh informasi bahwa kematangan kelamin dan pemijahan dapat dilakukan sepanjang tahun. Dari

\footnotetext{
Peneliti pada Balai Penelitian Perikanan Air Tawar, Sukamandi

") Pusat Riset Perikanan Budidaya
} 
aspek indeks ovisomatik (IOS), fekunditas stok ikan Cirata dan Wonogiri lebih besar daripada kedua stok ikan lainnya. Untuk tahun 2000 penelitian dilanjutkan dengan mengamati pertumbuhan dan sifat reproduksi (khususnya perkembangan gonad) dari generasi pertama keempat stok ikan tersebut.

Tujuan penelitian ini adalah untuk mengetahui pertumbuhan dan perkembangan gonad empat stok ikan baung (Cirata, Jatiluhur, Wadaslintang, dan Wonogiri) generasi pertama. Hal ini penting dilakukan untuk mengetahui stok yang paling produktif.

\section{BAHAN DAN METODE}

\section{Pemeliharaan calon induk generasi pertama empat stok ikan baung}

Generasi pertama empat stok ikan baung (Cirata, Jatiluhur, Wadaslintang, dan Wonogiri) diperoleh dari hasil pemijahan secara serentak pada tanggal 2 Agustus 1999. Kemudian keempat stok ikan baung masing-masing dipelihara di dalam Keramba Jaring Apung (KJA) berukuran $2 \times 2 \times 3 \mathrm{~m}^{3}$, dengan kepadatan masing-masing 40 ekor. Masing-masing stok dipelihara dalam tiga KJA, kecuali untuk Wadaslintang hanya dalam satu KJA. Jadi keseluruhan KJA yang dipergunakan adalah 10 buah. Komposisi jumlah betina dan jantan di dalam masing-masing jaring tidak semuanya sama karena bergantung kepada ketersediaan calon induk. Jumlah calon induk yang
$30 \%$ (Tabel 1 ) dengan ransum harian $3 \%$ bobot badan, dan frekuensi pemberian tiga kali per hari, yaitu pada pukul 09.00, 13.00, dan 17.00 WIB. Pakan ditebar di atas petakan berupa saringan halus ukuran $1 \times 1 \mathrm{~m}^{2}$ yang direndam pada kedalaman satu meter, sehingga pakan tidak lolos keluar jaring

\section{Pengamatan pertumbuhan}

Pengamatan pertumbuhan calon induk jantan dan betina dilakukan dengan penimbangan seluruh ikan masing-masing jenis kelamin pada setiap KJA.

$$
\frac{\text { Bobot jantan - bobot betina }}{\text { bobot betina }} \times 100 \%
$$

Pengamatan dilakukan sebulan sekali. Pertumbuhan jantan terhadap betina (\%), menggunakan rumus:

$$
\begin{aligned}
& \mathrm{LPH}=\sqrt[t]{\frac{W_{t}}{W_{0}}}-1 \times 100 \% \\
& \mathrm{PBH}=\frac{W_{t}-W_{0}}{t}
\end{aligned}
$$

Laju Pertumbuhan Harian (LPH) dan pertumbuhan Bobot Harian (PBH) dihitung berdasarkan Castel \& Tiews (1980).

\section{Pengamatan perkembangan gonad}

Kematangan ovari ikan betina ditunjukkan dengan tanda perut yang membengkak terutama di daerah

Tabel 1. Hasil analisis proksimat pakan yang digunakan dalam penelitian

Table 1. Proximate analysis of food given during experiment

\begin{tabular}{lc}
\hline \multicolumn{1}{c}{ Nutrien (Nutrient) } & Berdasarkan bobot kering (Dry basis) (\%) \\
\hline Air (Moistrure) & 0.00 \\
Protein (Protein) & 29.97 \\
Lemak (Fat) & 5.34 \\
Abu (Ash) & 10.55 \\
Serat kasar (Fiber) & 2.67 \\
Bahan ekstrak tanpa N (Nitrogen free extract) & 51.47 \\
\hline \multicolumn{2}{c}{ Jumlah (Total) } \\
\hline
\end{tabular}

diteliti dari seluruh stok adalah 389 ekor terdiri atas 204 betina dan 185 ekor jantan. Untuk stok Wadaslintang jumlah betina dan jantan masingmasing 8 dan 29. Penelitian dilaksanakan mulai bulan Oktober 2000 dan berlangsung selama 4 bulan. Ikan uji yang digunakan berumur 14 bulan dengan bobot berkisar antara 230-360 g/ekor.

Selama pemeliharaan ikan diberi pakan buatan berupa pelet komersial dengan kadar protein sekitar urogenital serta perkembangan oosit. Contoh oosit diambil dengan penyedotan menggunakan kateter berdiameter $2 \mathrm{~mm}$, melalui lubang genital sedalam $5 \mathrm{~cm}$. Telur yang diperoleh diawetkan dalam larutan buffer formalin. Selanjutnya perkembangan oosit diamati dengan cara mengukur besarnya (ukurannya) secara mikroskopis dengan menggunakan mikrometer. 
Untuk ikan jantan, kematangan kelamin dilihat dari ujung papila berwarna kemerah-merahan serta keluarnya cairan kalau dilakukan penyalinan.

\section{Sifat fisika dan kimia air}

Pengamatan suhu air (maksimum dan minimum) dilakukan setiap hari pada pukul $09 .{ }^{00}$ WIB pagi dengan menggunakan termometer maksimum dan minimum. Sifat fisika dan kimia air yang diamati yaitu $\mathrm{pH}$, kadar $\mathrm{O}_{2}$ terlarut, $\mathrm{CO}_{2}$ terlarut, alkalinitas, $\mathrm{N}-\mathrm{NH}_{4}$, dan $\mathrm{N}-\mathrm{NH}_{2}$.

\section{HASIL DAN BAHASAN}

Jumlah calon induk tersebut mengalami pengurangan karena adanya beberapa jaring yang
Bobot ikan dari masing-masing stok ikan pada setiap pengamatan dapat dilihat pada Tabel 3, sedangkan laju pertumbuhan harian dan pertumbuhan bobot harian tertera pada Tabel 4 .

Laju Pertumbuhan Harian (LPH) dan Pertumbuhan Bobot Harian (PBH) untuk semua stok ikan menunjukkan nilai yang relatif rendah. Hal ini dapat dipahami karena ikan sudah mulai matang gonad, sehingga energi banyak digunakan untuk perkembangan dan memelihara gonad. Sebagai perbandingan, LPH pada ikan yang sama pada ukuran yang berbeda, yaitu pada ukuran mulai sekitar $25 \mathrm{~g}$ menjadi sekitar 146-228 g per ekor jauh lebih cepat, dengan nilai LPH antara 0,92-1,29 (Hardjamulia \& Suhenda, 2000) (Tabel 4). Rendahnya laju pertumbuhan tersebut perlu dilihat dari aspek gizi, antara lain kebutuhan protein dan lemak

Tabel 2. Jumlah calon induk jantan dan betina ikan baung (Mystus nemurus) untuk setiap stok ikan pada akhir penelitian

Table 2. The amount of male and female green catfish broodstock at the end of the experiment

\begin{tabular}{lcc} 
& \multicolumn{2}{c}{ Akhir penelitian (Final experiment) } \\
\cline { 2 - 3 } Stok (Stock) & $\begin{array}{c}\text { Betina (ekor) } \\
\text { Female (number) }\end{array}$ & $\begin{array}{c}\text { Jantan (ekor) } \\
\text { Male (number) }\end{array}$ \\
\hline Cirata & $55(100.00)$ & $65(100.00)$ \\
Jatiluhur & $55(73.33)$ & $33(73.33)$ \\
Wadaslintang & $5(62.50)$ & $15(71.43)$ \\
Wonogori & $23(34.85)$ & $21(38.89)$ \\
\hline Jumlah/Total & $138(67.65)$ & $134(72.43)$ \\
\hline
\end{tabular}

Keterangan: Angka di dalam kurung menunjukkan persentase dari jumlah awal

Note: $\quad$ Value in the brackets was percentage of final to initial amount of broodstock

berlubang pada baris paling tepi dan menyebabkan sebagian ikan meloloskan diri ke luar jaring, sehingga jumlah calon induk yang ada pada akhir penelitian tercantum pada Tabel 2. yang diperlukan induk ikan untuk mulai matang gonad yang belum terungkap. Namun demikian dilihat dari kondisi ikan masih menunjukkan baik, yaitu ikan gemuk dengan proporsi yang dianggap masih normal.

Tabel 3. Bobot rata-rata individu (g) empat stok ikan baung (Mystus nemurus) generasi pertama pada setiap pengamatan

Table 3. Individual average weight ( $g$ ) of first generations of four green catfish stocks at each observation

\begin{tabular}{lccccc}
\hline $\begin{array}{c}\text { Stok } \\
\text { Stock }\end{array}$ & Oct. 2000 & Nov. 2000 & Dec. 2000 & Jan. 2001 & Feb. 2001 \\
\hline Cirata & $291.33(120)$ & $326.22(120)$ & $331.01(120)$ & $361.42(120)$ & $379.50(120)$ \\
Jatiluhur & $327.67(120)$ & $364.25(88)$ & $392.16(88)$ & $434.61(88)$ & $444.66(88)$ \\
W. Lintang & $281.02(29)$ & $375.17(29)$ & $367.46(29)$ & $397.59(29)$ & $414.50(50)$ \\
Wonogiri & $266.75(120)$ & $278.48(79)$ & $293.78(45)$ & $323.78(45)$ & $327.78(44)$ \\
\hline
\end{tabular}

Keterangan: Angka dalam kurung menunjukkan jumlah ikan yang diamati

Note: $\quad$ Value in brackets indicated the amount of experimental fish 
Tabel 4. Laju Pertumbuhan Harian (LPH) dan Pertumbuhan Bobot Harian (PBH) empat stok ikan baung (Mystus nemurus) generasi pertama pada fase dewasa

Table 4. Daily Growth Rate (DGR) and Aaverage Daily Growth (ADG) for four stocks of green catfish (Mystus nemurus) first generation

\begin{tabular}{lcc}
\hline \multicolumn{1}{c}{ Stok (Stock) } & $\begin{array}{c}\text { LPH (\%) } \\
\text { DGR(\%) }\end{array}$ & $\begin{array}{c}\text { PBH (g/hari) } \\
\text { ADG (g/day) }\end{array}$ \\
\hline Cirata & $0.19(1.21)^{*}$ & 0.64 \\
Jatiluhur & $0.22(1.29)$ & 0.85 \\
W.Lintang & $0.28(1.14)$ & 0.96 \\
Wonogiri & $0.15(0.92)$ & 0.44 \\
\hline
\end{tabular}

*) Nilai dalam kurung menunjukkan LPH dari gelondongan generasi pertama pemeliharaan dari 25 menjadi 146,5-228,4 g (Hardjamulia \& Suhenda, 2000)

*) The value in brackets indicated DGR of first generation green catfish during cultured from $25 \mathrm{~g}$ to 146.5 228.4 g (Hardjamulia \& Suhenda, 2000)

Tabel 4 menunjukkan bahwa nilai LPH dan PBH Wadaslintang lebih tinggi, mungkin karena jumlah ikan yang ada sedikit. Namun demikian pertumbuhan ikan stok Jatiluhur masih tetap menunjukkan nilai yang lebih baik dari kedua stok lainnya. Hal yang menarik adalah dari keempat stok tersebut menunjukkan bahwa ikan jantan lebih cepat pertumbuhannya daripada ikan betina (Gambar 1). Hal ini disebabkan induk jantan testisnya relatif kecil, sehingga energi yang diperoleh dari pakan yang diberikan dimanfaatkan ikan untuk pertumbuhan tubuhnya. Besarnya persentase pertambahan bobot ikan jantan terhadap betina cukup besar yaitu antara $11,65 \%$ sampai $15,97 \%$ (Tabel 5)

Jumlah ikan betina (\%) yang matang ovari dari setiap stok dapat dilihat pada Gambar 2. Pada bulan
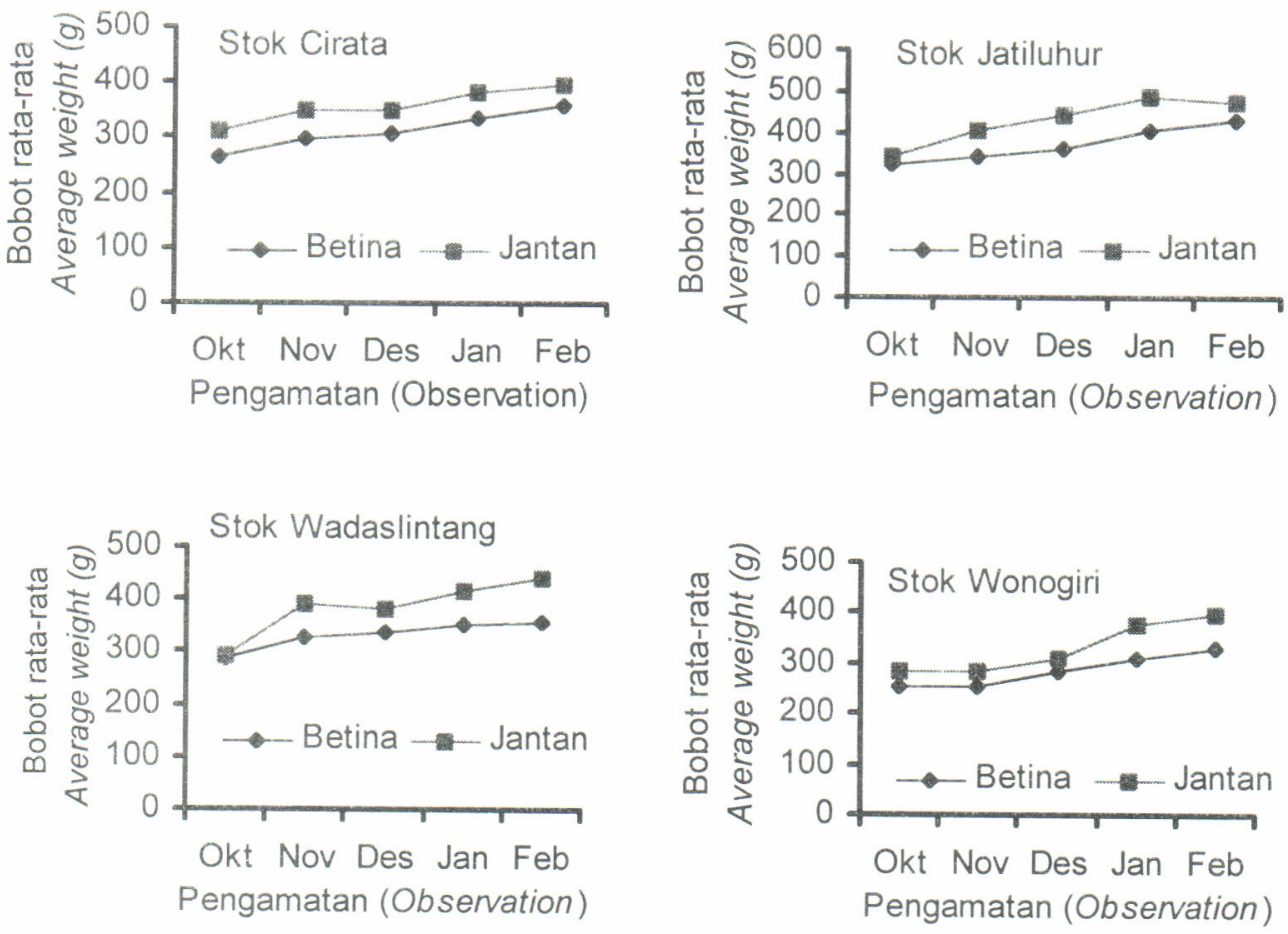

Gambar 1. Bobot $(\mathrm{g})$ ikan baung jantan dan betina fase dewasa setiap pengamatan Figure 1. Body weight of adult male and female green catfish during experiment 
Tabel 5. Perbedaan pertumbuhan ikan baung (Mystus nemurus) jantan terhadap betina (\%) pada setiap pengamatan

Table 5. Growth differences between male and female of green catfish (Mystus nemurus) during experiment

\begin{tabular}{lcccccc}
\hline Stok Stock & Oct. & Nov. & Dec. & Jan. & Feb. & $\begin{array}{c}\text { Rata-rata } \\
\text { Average }\end{array}$ \\
\hline Cirata & 18.14 & 18.25 & 14.90 & 14.25 & 11.19 & $15.35 \pm 2.95$ \\
Jatiluhur & 6.16 & 20.04 & 21.93 & 19.70 & 9.68 & $15.50 \pm 7.08$ \\
W. Lintang & 3.22 & 20.10 & 11.96 & 17.79 & 26.78 & $15.97 \pm 8.89$ \\
Wonogiri & 13.60 & 19.09 & 9.54 & 9.22 & 6.82 & $11.65 \pm 4.82$ \\
\hline
\end{tabular}

Februari 2001 jumlah induk betina stok Jatiluhur yang matang gonad mencapai $95 \%$. Pada bulan November, Desember 2000, dan Januari 2001, stok ikan Jatiluhur memberikan induk matang gonad dalam jumlah tertinggi, karena stok ikan ini mudah beradaptasi terhadap lingkungan (KJA) daripada stok lainnya
Sebagai perbandingan, pada induk asalnya yang diperoleh dari hasil tangkapan di alam dan umurnya tidak diketahui, kematangan ovari didapatkan pada ikan dengan bobot antara 185-1.320 g (Hardjamulia \& Suhenda, 2000). Induk ikan yang berukuran besar $(1.320 \mathrm{~g})$ tersebut diperoleh dari Waduk Wonogiri. Dari Waduk Cirata diperoleh dengan ukuran $1.200 \mathrm{~g}$ dan

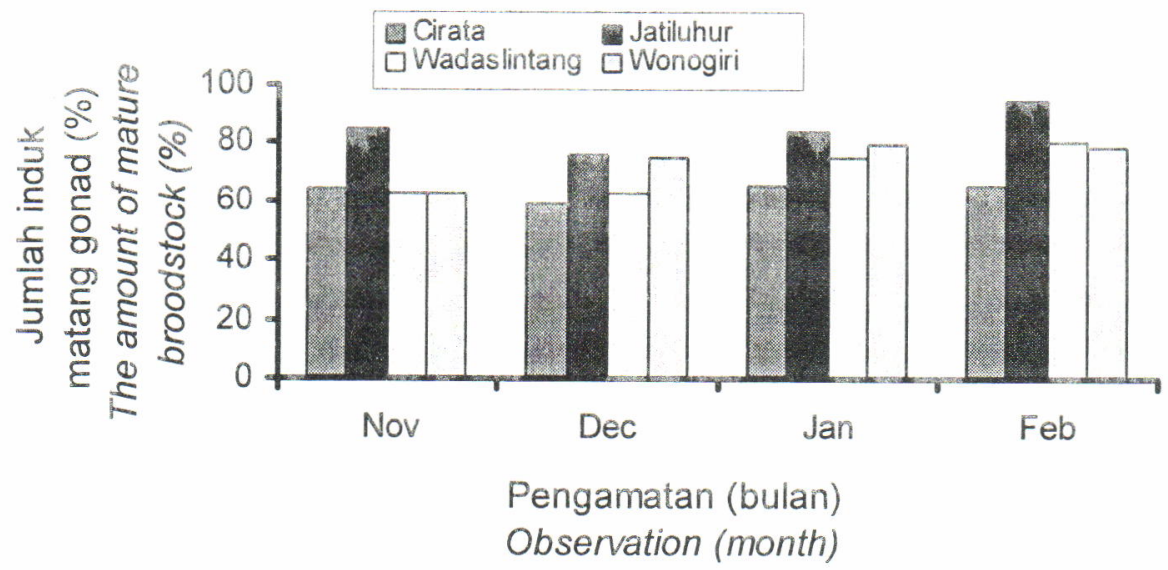

Gambar 2. Persentase jumiah induk betina ikan baung (Mystus nemurus) matang gonad dari masing-masing stok

Figure 2. The percentage of mature female of green catfish (Mystus nemurus) broodstock

yang ditunjukkan oleh tingkat kematangan gonadnya. Untuk stok Cirata, meskipun penelitian dilakukan di Waduk Cirata, jumlah induk yang matang gonad lebih kecil (36\%) dari ketiga stok lainnya. Gambar 2 menunjukkan pula bahwa ikan baung generasi pertama, hasil pemijahan 2 Agustus 1999 sudah dapat matang kelamin pada umur sekitar 16 bulan (pada bulan November 2000), dengan bobot antara 250-340 g. Hasil pengamatan mengenai kondisi perairan pada waktu penelitjan menunjukkan bahwa suhu air minimum dan maksimum dari bulan Maret 2000 sampai Febuari 2001 yaitu $27^{\circ} \mathrm{C}$ dan $31^{\circ} \mathrm{C}$. Suhu terendah $\left(27^{\circ} \mathrm{C}\right)$ diperoleh bulan Maret, sedangkan suhu maksimum $\left(31,0^{\circ} \mathrm{C}\right)$ diperoleh pada bulan Mei, Juni, September, dan Oktober 2000. Sifat fisika kimia air (pengamatan pukul 09.00 WIB) lainnya yaitu $\mathrm{pH} 7,5$ dan oksigen terlarut $4,20 \mathrm{mg} / \mathrm{L}$.
Waduk Jatiluhur diperoleh induk dengan ukuran 800 g. Ikan betina yang matang gonad dilihat secara visual, diameter telur yang diperoleh 1,37-1,63 mm.

\section{KESIMPULAN}

1. Pertumbuhan empat stok ikan baung generasi pertama relatif lambat setelah berukuran sekitar 170 g. Stok Wadaslintang dan Jatiluhur pertumbuhannya lebih baik daripada kedua stok lainnya.

2. Ikan baung betina generasi pertama telah dapat matang kelamin pada umur 16 bulan, yang dimulai pada bulan November 2000. Untuk stok Jatiluhur, kematangan gonadnya tertinggi (sekitar 95\%) dibandingkan dengan kematangan gonad stok lainnya. 


\section{DAFTAR PUSTAKA}

Alawi, H., M. Ahmad, Rusliadi, dan Pardinan. 1992. Some biological aspects of macrones catfish (Macrones nemurus C.V.) from Kampar River. Terubuk XVII. 52: $32--47$

Amornsakun, T. 1999. Some aspects in early life stages on larvae red-tail catfish, Mystus wyckioides. Songklanakarin J. Sci. Technol. 21 (4): 401--406.

Amornsakun, T. 2000. Influences of initial delay of feeding on growth and survival of red-tail catfish, Mystus wyckioides. Songklanakarin J. Sci. Technol. 22 (1): 51--55.

Castel, J.D. and Tiews, K. 1980. Reports of the EIFAC, IUNS, and ICES Working Group on Standardization of Methodology in Fish Nutrition Research. EIFAC Technical Paper No. 36. FAO Rome. 24 pp.

Gaffar, A.K. dan N. Muflikhah. 1992. Pemijahan buatan dan pemeliharaan larva ikan baung. Pros. Seminar Hasil Penelitian Perikanan Air Tawar 1991/1992. Balitkanwar, Bogor. p. 254--257.

Hardjamulia, A. dan N. Suhenda. 2000. Evaluasi sifat reproduksi dan sifat gelondongan generasi pertama empat stok ikan baung (Mystus nemurus) di keramba jaring apung. Jurnal Penelitian Perikanan Indonesia. Vol. 6, No. 3--4: 24--35.
Muflikhah, N. dan A.K. Gaffar. 1992. Pengaruh perbedaan padat tebar terhadap pertumbuhan ikan baung (Mystus nemurus) di kolam stagnan. Bull. Perikanan Perikanan Darat. 11(2): 129--133.

Muflikhah, N., Yosmaniar, dan M. Jahri. 1993. Penelitian tehnik kawin rangsang dan budi daya ikan baung (Mystus nemurus C.V.). Laporan Rakernis Balitkanwar Sukamandi 24--26 Mei 1993. 10 pp.

Muflikhah, N. dan S.N. Aida. 1996. Pengaruh frekuensi pemberian pakan yang berbeda terhadap pertumbuhan dan kelangsungan hidup benih ikan baung (Mystus nemurus). Prosiding Lolitkanwar No. 2/1996. p. 108--111.

Nasution, Z., A.D. Utomo, D. Prasetyo, dan S. Yusuf. 1993. Kajian ekonomi pada sumber daya perikanan baung di DAS Batanghari, Propinsi Jambi. Laporan Rakernis Balitkanwar Sukamandi 24--26 Mei 1993.

Robert, T.R. 1989. The Freshwater Fishes of Western Borneo (Kalimantan Barat, Indonesia). California Academy of Science. 210 pp.

Samuel, S. Adjie, dan Akrimi. 1995. Beberapa Aspek Biologi Ikan Baung (Mystus nemurus) di Daerah Aliran Sungai Batanghari, Propinsi Jambi. Oseanologi dan Limnologi di Indonesia 28: 1--13.

Sukendi. 2001. Biologi Reproduksi dan Pengendaliannya dalam Upaya Pembenihan Ikan Baung (Mystus nemurus) di Perairan Sungai Kampar Riau. Disertasi. Program Pascasarjana IPB. 


\title{
POLA LEMAK NON-POLAR, POLAR, DAN ASAM LEMAK ESENSIAL PADA PERKEMBANGAN LARVA IKAN KERAPU BEBEK (Cromileptes altivelis) TAHAP AWAL
}

\begin{abstract}
Ketut Suwirya, Tridjoko, dan Nyoman Adiasmara Giri
ABSTRAK

Perkembangan larva pada tahap awal sangat bergantung pada energi yang tersedia padanya. Salah satu bentuk energi yang tersedia pada telur dan larva pada tahap awal adalah lemak. Lemak dalam perkembangan telur dan larva pada tahap awal digunakan sebagai energi dan memelihara membran sel. Oleh karena itu, proporsi kelas lemak yang digunakan sebagai energi akan turun dan kelas lemak yang digunakan untuk memelihara membran akan naik. Kualitas dari lemak juga bergantung pada kandungan asam lemak esensial yang terdapat pada telur dan larva. Penelitian ini bertujuan untuk mengetahui metabolisme lemak pada masa perkembangan telur dan larva pada tahap awal sebagai informasi dasar dalam penentuan ransum induk. Kelas lemak non-polar, polar, dan asam lemak dari telur phase neurula dan larva umur $0,1,3,4,7,12$, dan 15 hari diamati kelas lemak non-polar, polar, dan asam lemak esensialnya. Hasil pengamatan menunjukkan bahwa proporsi kelas lemak non-polar dari telur phase neurula sampai larva umur 3 hari (D3) menurun dari $87,76 \%$ sampai $43,62 \%$, dan lemak polar meningkat dari $12,24 \%$ sampai $56,36 \%$. Hal ini menunjukkan bahwa kelas lemak non-polar digunakan sebagai energi dan kelas lemak polar digunakan untuk memelihara membran sel tubuh. Asam lemak esensial seperti EPA dan DHA nampak mengalami penurunan baik pada lemak non-polar maupun pada lemak polar. Penurunan asam lemak esensial tersebut lebih tinggi pada kelas lemak non-polar dibandingkan dengan kelas lemak polar.
\end{abstract}

ABSTRACT: The patterns of non-polar, polar lipid, and essential fatty acid in early development of humpback grouper, Cromileptes altivelis larvae. By: Ketut Suwirya, Tridjoko, and Nyoman Adiasmara Giri

Development of early stage of larvae depends on the energy content of the body. One of energy sources in early stage of larvae is lipid. Lipid in eggs and early development lanae stage is used for energy and maintaining membrane of body cells. Therefore class lipid for energy decreases and class lipid for maintained membrane increases. Lipid quality in larvae depends on the content of essential fatty acid. The experiment was done to know the lipid metabolism in eggs development and early stage of larvae. This basic information can be used in feed formulation for broodstock of humpback grouper. Lipid from larvae stage neurola, 0, 1, 3, 4, 7, 12, and 15 days after hatch out were observed on their non-polar, polar lipid, and essential fatty acids. The result of experiment showed that proportion of non-polar lipid from neurola phase to three-day larvae (D3) decreased from $87.76 \%$ to $43.62 \%$ and polar lipid increased from $12.24 \%$ to $56.36 \%$. This result showed that non-polar lipid was used for energy and polar lipid for maintaining membrane of body cell. Essential fatty acids, such as EPA and DHA also decreased in non-polar and polar lipids. Decreased essential fatty acid was higher in non-polar lipid than in polar lipid.

KEYWORDS: essential fatty acid, humback grouper

\section{PENDAHULUAN}

Perkembangan telur dan larva pada tahap awal sangat bergantung pada energi bawaan (endogenous energy) yang tersedia padanya. Salah satu bentuk energi yang tersedia pada telur dan larva pada tahap awal adalah lemak. Lemak pada telur dan larva pada tahap awal digunakan sebagai energi dan memelihara membran sel. Dalam perkembangan larva kerapu bebek (Cromileptes altivelis) pada saat belum dapat makan yaitu dari D0 sampai larva D3 maka akan ada kecenderungan proporsi kelas lemak yang digunakan sebagai energi akan turun dan kelas lemak yang digunakan untuk memelihara membran akan naik. Pola perubahan kelas lemak ini akan sangat bergantung dari kualitas lemak yang ditentukan oleh kandungan asam lemak esensial yang terdapat pada telur dan larva. Asam lemak yang esensial pada ikanikan laut adalah dari kelompok n-3 HUFA seperti asam lemak eikosapentanoat (EPA) dan dokosahexaenoat (DHA). Hal ini dapat dilihat dari hasil penelitian pada ikan striped jack (Takauchi et al., 1992); Oplegnatus

Peneliti pada Balai Besar Riset Perikanan Budidaya Laut, Gondol 
fasciatus (Kanazawa, 1993); red sea bream (Furuita et al., 1996); dan kerapu bebek (Suwirya et al., 2001).

Kelompok asam lemak n-3 high unsaturated fatty acids (n-3 HUFA) seperti EPA (20:5n-3) dan DHA $(22: 6 n-3)$ adalah komponen penyusun penting membran sel, terutama pada otak dan retina (Watanabe et al., 1993) dan asam lemak tersebut sangat dibutuhkan pada stadia awal perkembangan larva untuk mendukung perkembangan organ visual dan syaraf secara normal (Sargent et al., 1993).

Pengamatan ini difokuskan pada lemak dari telur fase neurula sampai larva pada tahap awal. Penelitian bertujuan untuk mendapatkan informasi biokimia dasar penggunaan lemak dalam proses perkembangan telur sampai larva kerapu bebek tahap awal sebagai informasi dasar untuk penyusunan nutrisi pakan induk.

\section{BAHAN DAN METODE}

Sampel diambil dari telur fase neurula dan larva umur $0,1,3,4,7,12$, dan 15 untuk digunakan pada analisis lemak polar, non-polar, dan analisis asam lemak. Telur kerapu bebek diinkubasi pada 8 bak fiber volume $100 \mathrm{~L}$ dengan kepadatan 30 butir/L, kemudian telur tersebut dipanen masing-masing 2 bak metilester dilakukan dengan alat gas Chromatography merk Antex-3000 dengan nyala detektor ionisasi dan melalui stainless column BFT 10 \% DEGS (Diethyleneglycolsuccinate) 80/100 1900la-III. Sampel diinjeksi pada suhu $200^{\circ} \mathrm{C}$. Setelah 1 menit temperatur naik $0,8^{\circ} \mathrm{C}$ per menit hingga mencapai $230^{\circ} \mathrm{C}$ dan tetap pada suhu ini selama ekstra 1,5 menit. Temperatur injektor dan detektor diatur pada suhu $220^{\circ} \mathrm{C}$. Nitrogen $(30 \mathrm{~mL} /$ menit) digunakan sebagai gas pembawa. Asam lemak diidentifikasi dengan cara membandingkan kromatografi hasil ilusi dengan larutan standar dan data disajikan dalam persentase dari total asam lemak.

\section{HASIL DAN BAHASAN}

Proporsi kelas lemak non-polar dari telur fase neurula sampai larva D3 mengalami penurunan yaitu dari $87,76 \%$ sampai $43,62 \%$ dan kemudian cenderung stabil pada larva D4--D15 dengan kisaran 43,21\%-$48,87 \%$ (Tabel 1). Kandungan EPA dan DHA lemak non-polar pada telur fase neurula lebih banyak dari pada larva umur D1-D4. Kedua asam lemak tersebut mulai meningkat setelah larva D4, karena larva mulai mengkonsumsi makanan dari luar (Gambar 1). Proporsi asam lemak DHA pada telur dan larva DO

Tabel 1. Proporsi lemak polar dan non-polar pada lemak tubuh larva stadia awal Table 1. Proportion of polar and non-polar lipid of body larvae in early stage

\begin{tabular}{lccccccccc}
\hline \multirow{2}{*}{$\begin{array}{c}\text { Kelas lemak } \\
\text { Lipid class }\end{array}$} & $\begin{array}{c}\text { Telur } \\
\text { egg }\end{array}$ & D 0 & D 1 & D 3 & D 4 & D 7 & D 12 & D15 \\
\hline Non-polar & 87.76 & 71.11 & 60.21 & 43.62 & 48.87 & 39.96 & 36.55 & 43.21 \\
Polar & 12.24 & 28.89 & 39.79 & 56.36 & 51.13 & 60.04 & 63.45 & 56.79 \\
\hline Total & 100 & 100 & 100 & 100 & 100 & 100 & 100 & 100 \\
\hline
\end{tabular}

pada fase neurula, larva D0, D1, dan D3 dengan menggunakan plankton net dan disimpan pada suhu $-20^{\circ} \mathrm{C}$ sebelum dianalisis. Untuk larva umur D4, D7, D12, dan D15 diambil dari bak pemeliharaan massal hatcheri kerapu bebek yang diberi pakan berupa rotifer. Larva berumur 7, 12, dan 15 hari dipindahkan ke dalam 3 bak fiber volume $100 \mathrm{~L}$ dengan kepadatan 15 ekor per liter untuk dipuasakan selama 0,12, dan 24 jam dan setelah itu dipanen.

Total lemak dari sampel larva diekstrak dengan metode Bligh \& Dyer (1959). Lemak dipisahkan menjadi lemak polar dan non-polar dengan silica cartridge (Sep-pack, Waters S.A. Milford) seperti yang dijelaskan oleh Juaneda \& Rocquelin (1985). Asam lemak dalam bentuk metylester dipreparasi dengan menggunakan Boron Trifluoride dan Dichloromethane menurut metode Metcalfe \& Schmitz (1961). Analisis lebih tinggi daripada EPA, sedangkan pada larva D1 sampai D3 berlangsung sebaliknya yaitu EPA lebih besar dari DHA. Hal ini terjadi karena jaringan tubuh berkembang sehingga DHA banyak digunakan dalam penyusunannya. Seperti yang dikemukakan oleh Mourente \& Odriozola (1990) bahwa keberadaan DHA yang lebih tinggi pada telur ikan menunjukkan peranan penting dalam formasi lemak membran selama organogenesis dari embrio dan larva. Penurunan lemak nonpolar dalam tubuh larva yang belum mendapat pakan dari luar menunjukkan bahwa lemak nonpolar merupakan cadangan energi yang digunakan pada fase tersebut agar metabolisme berjalan dengan baik.

Proporsi kelas lemak polar terus mengalami peningkatan dari $12,24 \%$ sampai $56,36 \%$ pada telur fase neurula hingga larva umur D4 (Tabel 1). Namun kandungan asam lemak esensial pada lemak polar 


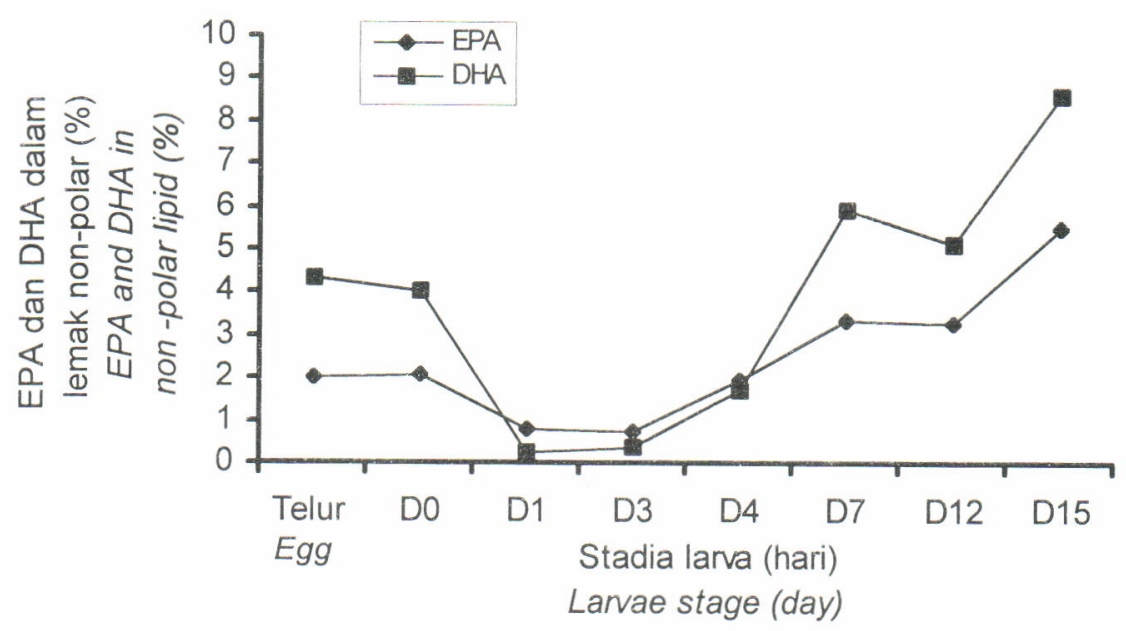

Gambar 1. EPA dan DHA pada lemak non-polar dari larva stadia awal

Figure 1. EPA and DHA in non-polar lipid of early larvae stage

seperti EPA dan DHA juga terus mengalami penurunan dari telur fase neurula hingga larva umur D3 dan kemudian meningkat kembali mulai larva D4. Asam lemak DHA lebih rendah dari EPA pada larva DO-D4 dan setelah D4 sebaliknya yaitu DHA lebih tinggi dari EPA (Gambar 2). Hal ini ada hubungannya dengan perkembangan larva dan tidak adanya pemasukan sumber DHA dari luar pada larva DO sampai D3 karena larva belum makan. Kejadian yang sebaliknya terjadi begitu larva mendapat pakan dari luar yaitu setelah larva berumur 4 hari (D4) di mana larva mulai makan rotifer. Di samping itu, DHA lebih labil pada saat larva tidak makan jika dibandingkan dengan EPA yang mungkin ada hubungannya dengan dinamika sel tubuh. Penelitian Leray et al. (1985) terhadap perkembangan embrio dan larva ikan rainbow trout mencatat bahwa senyawa DHA dan EPA pada lemak polar cenderung ditahan dalam jaringan larva, sehingga bentuk ini lebih stabil hingga mencapai saat larva siap makan.

Proporsi asam lemak EPA dan DHA pada lemak polar selalu lebih banyak daripada konsentrasi asam lemak EPA dan DHA pada lemak non-polar (Gambar 1 dan Gambar 2). Hal ini menunjukkan bahwa kedua asam lemak tersebut konsentrasinya lebih banyak pada membran daripada lemak yang dapat dimanfaatkan sebagai energi. EPA dan DHA dalam polar lipid sifatnya lebih permanen untuk menjaga keutuhan fermiabel sel tubuh.

Dari sampel lemak yang diambil pada larva D7, D12, dan D15 yang dipuasakan antara 12 sampai 24 jam menunjukkan proporsi lemak polar mengalami kenaikan dan non-polar mengalami penurunan,

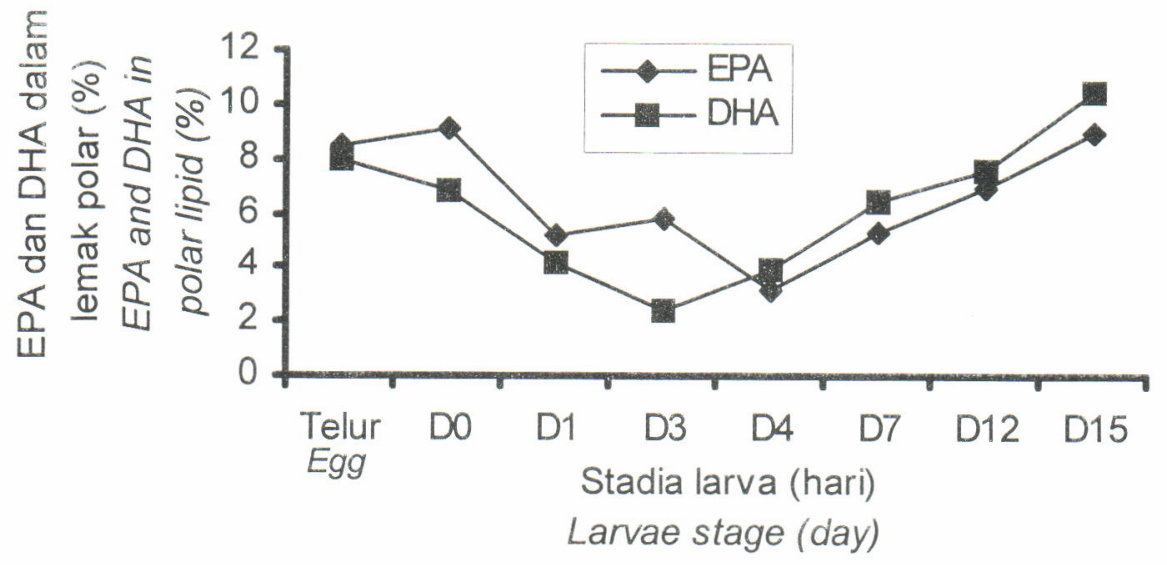

Gambar 2. EPA dan DHA pada lemak polar dari larva stadia awal

Figure 2. EPA and DHA in polar lipid of early larvae stage 
demikian juga EPA dan DHA baik pada lemak polar maupun non-polar mengalami penurunan (Tabel 2). $\mathrm{Hal}$ ini menunjukkan pola yang sama dengan larva umur D0 sampai D3. Kenaikan lemak polar dan penurunan non-polar pada larva umur D0-D3 dan setelah dipuasakan pada larva umur D7, D12, dan D15 menunjukkan bahwa lemak polar dipergunakan untuk menjaga membran sel dan lemak non-polar digunakan sebagai energi untuk bertahan hidup dan berkembang. Hal ini sesuai dengan yang dikemukan oleh Watanabe (1988) bahwa lemak selain sebagai sumber energi juga digunakan untuk menjaga struktur sel, perawatan tubuh, dan untuk mempertahankan integritas pada biomembran. DHA sangat dibutuhkan dalam menjaga struktur membran dan menjaga fungsi enzimatik membran sel (Castledine \& Buckley, 1980).

Larva yang berumur 7, 12, dan 15 hari kalau dipuasakan selama 12 sampai 24 jarn, maka rasio DHA : EPA cenderung menurun baik pada kelas lemak polar maupun non-polar. Metabolisme selama untuk bertahan hidup dan berkembang sebelum mampu mendapatkan makanan dari luar. Nurdjana (1986) menyatakan bahwa lemak memegang peranan penting sebagai sumber energi utama bagi proses metabolisme, akan tetapi pemanfaatan sumber energi tersebut berbeda pada setiap stadia. Pada penelitiannya terhadap udang windu (Penaeus monodon), Nurdjana (1986) menyatakan bahwa lemak memegang peran penting sebagai sumber energi utama bagi proses metabolisme stadium nauplius, sehingga kuantitas dan kualitas lemak yang menyusun kuning telur menentukan kualitas telur tersebut dalam hubungannya dengan kuning telur sebagai cadangan makanan bagi larva yang dihasilkan.

Konsentrasi asam lemak EPA dan DHA polar dan non-polar pada larva D12 dan D15 yang dipuasakan selama 12 jam mengalami peningkatan. Hal ini menunjukkan bahwa asam lemak yang lain digunakan lebih awal sebagai energi untuk menjaga proses metabolisme tubuh. Tandler et al. (1995) menyatakan

Tabel 2. Proporsi lemak non-polar dan polar serta EPA dan DHA pada lemak polar dan non polar dari larva yang dipuasakan selama 0,12 , dan 24 jam

Table 2. Non-polar and polar lipid proportion and EPA and DHA content in each class lipid in larvae was fasted for 0, 12, and 24 hours

\begin{tabular}{|c|c|c|c|c|c|c|c|c|}
\hline \multirow{3}{*}{$\begin{array}{l}\text { Kelas lemak/EPA dan DHA } \\
\text { Class lipid/EPA and DHA }\end{array}$} & \multicolumn{8}{|c|}{$\begin{array}{c}\text { Stadia larva dan lama pemuasaan } \\
\text { Lanve stage and fasting period }\end{array}$} \\
\hline & \multicolumn{2}{|c|}{ D 7} & \multicolumn{3}{|c|}{ D 12} & \multicolumn{3}{|c|}{ D 15} \\
\hline & 0 & 12 & 0 & 12 & 24 & 0 & 12 & 24 \\
\hline Non-polar & 39.96 & 27.73 & 36.55 & 35.29 & 27.44 & 43.21 & 41.47 & 35.48 \\
\hline EPA & 3.37 & 7.29 & 3.10 & 4.28 & 1.70 & 5.48 & 5.68 & 5.07 \\
\hline $\mathrm{DHA}$ & 5.89 & 2.87 & 5.15 & 5.11 & 2.04 & 8.58 & 9.97 & 6.78 \\
\hline Asam lemak lainnya (Other fatty acids) & 30.70 & 17.57 & 28.30 & 25.90 & 23.70 & 29.15 & 25.82 & 23.63 \\
\hline Ratio DHA/EPA & $(1.75)$ & $(0.39)$ & $(1.66)$ & $(1.12)$ & $(1.20)$ & $(1.57)$ & $(1.75)$ & $(1.34)$ \\
\hline Polar & 60.04 & 72.67 & 63.45 & 64.71 & 72.56 & 56.79 & 58.53 & 64.52 \\
\hline EPA & 5.30 & 4.84 & 6.93 & 9.35 & 7.87 & 8.99 & 9.38 & 7.74 \\
\hline $\mathrm{DHA}$ & 6.46 & 3.57 & 7.62 & 7.86 & 6.44 & 10.54 & 8.57 & 5.95 \\
\hline Asam lemak lainnya (Other fatty acids) & 48.28 & 64.26 & 48.90 & 47.5 & 58.25 & 37.26 & 40.58 & 50.83 \\
\hline Ratio DHA/EPA & (1.22) & $(0.74)$ & $(-1.1)$ & $(0.84)$ & $(1.10)$ & $(1.17)$ & $(0.91)$ & $(0.77)$ \\
\hline Total (NL+PL) & 100 & 100 & 100 & 100 & 100 & 100 & 100 & 100 \\
\hline
\end{tabular}

dipuasakan ini lebih banyak menggunakan DHA daripada EPA atau mungkin EPA dapat terbentuk dari rantai asam lemak keluarga $n-3$ dari rantai yang lebih rendah.

Kandungan asam lemak EPA dan DHA pada lemak polar dan non-polar pada telur fase neurula lebih tinggi daripada larva. Hal tersebut erat kaitannya dengan cadangan makanan yang digunakan larva bahwa peningkatan relatif terjadi pada n-3 fatty acids yang berasosiasi seiring dengan kehilangan makanan dan DHA atau esensial HUFA yang lain selalu diperbaharui karena mereka dibutuhkan dalam proses metabolisme

Pada pemuasaan 24 jam konsentrasi asam lemak EPA dan DHA baik polar ataupun non-polar mengalami penurunan. Hal ini menunjukkan bahwa telah terjadi 
degradasi asam lemak dalam tubuh larva. Larva menggunakan energi cadangannya untuk bertahan hidup dalam kondisi tanpa makanan dari luar. Seperti yang diungkapkan Chang \& Idler (1960) bahwa ikan menggunakan lemak sebagai sumber energi utama selama periode tanpa makanan.

Pada larva umur D4, D7, D12, dan D15 konsentrasi DHA baik polar ataupun non-polar terus meningkat dan lebih tinggi daripada konsentrasi EPA polar dan non polar, yaitu dengan rasio $1,10--1,75$. Tingginya tingkat konsentrasi DHA pada larva yang telah mengkonsumsi makanan dari luar mengindikasikan bahwa DHA lebih berperan daripada EPA bagi pertumbuhan dan sintasan larva. Pola yang sama terjadi pada larva Knife Jaw (Oplegnatus fasciatus) dan Striped Jack (Caranx delicatissimus) seperti yang telah dilaporkan oleh Kanazawa (1993). EPA dan DHA
Komposisi asam lemak dari total lemak dari larva kerapu bebek stadia awal pada Tabel 3 terlihat bahwa penurunan EPA lebih lambat dari DHA pada larva DO sampai D3. Hal ini dapat dilihat dari rasio EPA dan DHA yang bergerak dari 0,85 pada D0 dan 1,11 pada D3. Namun begitu larva mendapat pakan dari luar maka kandungan DHA melebihi EPA yaitu ditunjukkan oleh rasio EPA dan DHA antara 0,90 sampai 0,77 pada larva D4 sampai D15.

Pada perkembangan larva sebelum mendapat pakan dari luar lebih banyak memanfaatkan asam lemak palmitat (16:0) dibandingkan n-3 HUFA. Hal ini ditunjukkan oleh rasio asam lemak palmitat (16:0) dengan n-3 HUFA (Tabel 3) yaitu bergerak dari 3,9 pada telur fase neurula sampai 2,99 pada D3. Larva mulai makan yang pertama pada umur 4 hari (D4). Dari Tabel 3 nampak bahwa konsentrasi palmitat pada

Tabel 3. Komposisi asam lemak dari lemak total larva kerapu bebek pada telur stadia neurula, DO, D1, D3, D4, D7, D12, dan D15 (\% area)

Table 3. Fatty acid composition of total lipid of humpback grouper larvae in neurula stage, DO, D1, D3, D4, $D 7, D 12$, and D15 (\% area)

\begin{tabular}{|c|c|c|c|c|c|c|c|c|}
\hline \multirow{2}{*}{$\begin{array}{l}\text { Asam lemak } \\
\text { Fatty acid }\end{array}$} & \multicolumn{8}{|c|}{ Stadia (stage) } \\
\hline & $\begin{array}{l}\text { Telur } \\
\text { Egg }\end{array}$ & D 0 & 01 & D 3 & D 4 & D7 & D 12 & D15 \\
\hline Miristik (myristic acid) (14:0) & 5.54 & 4.05 & 3.71 & 2.09 & 4.61 & 2.74 & 2.83 & 2.83 \\
\hline Palmitat $(16: 0)$ & 29.96 & 34.68 & 26.87 & 20.16 & 36.74 & 33.52 & 32.90 & 30.11 \\
\hline Palmitoleat (palmitoleic acid) $(16: 1 n-9)$ & 18.78 & 17.54 & 12.42 & 11.17 & 15.63 & 18.02 & 19.29 & 18.41 \\
\hline Oleat (oleic acid)(18:1n-9) & 15.82 & 13.54 & 9.51 & 8.17 & 10.57 & 8.99 & 8.59 & 8.75 \\
\hline Linolenat (linolenic acid) (18:3n-3) & 20.60 & 20.15 & 32.05 & 40.17 & 22.54 & 20.04 & 16.86 & 16.52 \\
\hline Arasidonat (arachidonate acid) $(20: 4 n-6)$ & 1.24 & 0.28 & 2.02 & 3.79 & 0.73 & 1.04 & 0.86 & 0.96 \\
\hline $\operatorname{EPA}(20: 5 n-3)$ & 2.88 & 4.09 & 3.56 & 3.55 & 2.50 & 4.53 & 5.61 & 7.48 \\
\hline DHA $(22: 6 n-3)$ & 4.78 & 4.81 & 3.86 & 3.20 & 2.79 & 6.23 & 6.34 & 9.70 \\
\hline $\mathrm{NN}^{*}$ & 0.40 & 0.86 & 0.00 & 7.70 & 3.88 & 4.90 & 4.35 & 5.20 \\
\hline n-3 HUFA & 7.66 & 8.90 & 6.22 & 6.75 & 5.29 & 10.76 & 12.33 & 17.18 \\
\hline Ratio EPA : DHA & 0.60 & 0.85 & 1.33 & 1.11 & 0.90 & 0.73 & 0.83 & 0.77 \\
\hline Palmitat : n-3HUFA & 3.91 & 3.89 & 3.62 & 2.99 & 6.95 & 3.11 & 2.66 & 1.75 \\
\hline
\end{tabular}

*Asam lemak yang tidak dapat diidentifikasi (Non identified fatty acid)

merupakan komponen terbesar pembentuk membran sel, walaupun pada beberapa studi menunjukkan bahwa DHA lebih superior daripada EPA sebagai asam lemak esensial (Watanabe, 1983).

Kadar asam lemak esensial lebih tinggi dan stabil pada larva D15 dibanding pada larva D7 dan D12. Larva D15 lebih sedikit menggunakan cadangan energi dari asam lemak esensial untuk metabolisme pada kondisi tanpa pakan. Hal ini mengindikasikan bahwa larva D15 mempunyai vitalitas yang lebih baik daripada larva D7 dan D12. larva D4 meningkat sangat tinggi sedangkan konsentrasi n-3 HUFA tidak berbeda jauh dibandingkan larva D3. Rasio asam lemak palmitat (16:0) dan n-3 HUFA pada larva D4-15 (Tabel 3) menunjukkan penurunan dari 6,95 menjadi 1,75. Hal ini dapat disebabkan kadar n-3 HUFA rendah dalam pakan sehingga peningkatannya dalam tubuh menjadi lambat.

\section{KESIMPULAN}

Kelas lemak non-polar digunakan sebagai energi dan lemak polar digunakan untuk memelihara 
membran sel pada tahap awal larva kerapu bebek. Persediaan DHA yang lebih tinggi daripada EPA pada telur menunjukkan bahwa DHA lebih labil serta berperan dalam pertumbuhan dan menjaga vitalitas larva kerapu bebek. Asam lemak esensial seperti EPA dan DHA nampak mengalami penurunan baik pada lemak non-polar maupun pada lemak polar. Penurunan asam lemak esensial tersebut lebih tinggi pada kelas lemak non-polar dibandingkan dengan kelas lemak polar.

\section{DAFTAR PUSTAKA}

Bligh, E.G. and W.J. Dyer. 1959. A rapid method of total lipid extraction and purification. Can. J. Biochem. Physol. 37: 911--917.

Castledine, A.J. and J.T. Buckley. 1980. Distribution and mobility of 3 fatty acid in rainbow trout varying levels and types of dietary lipid. J. Nutr. 110: 675--685.

Chang, V.M. and D.R. Idler. 1960. Biochemical studies on sockeye salmon during spawning migration. XII. Liver Glycogen. Can. J. Biochem. Physol. 38: 553-558.

Furuita, H., T. Takeuchi, M. Toyota, and T. Watanabe. 1996. EPA and DHA requirements in early juvenile red sea bream using HUFA enriched Artemia nauplii. Fish. Sci. 62(2): 246--251.

Juaneda, P. and G. Rocquelin. 1985. Rapid and convenient separation of phospholipids and nonphosphorus lipids from rat using silica cartridges. Lipids 20: 40--41.

Kanazawa, A. 1993. Importance of dietary docosahexaenoic acid on growth and survival of fish larvae. In C.S. Lee, M.S. Su and I.C. Liao (Eds.) Finfish Hatchery in Asia: Proceedings of Finfish Hatchery in Asia 91. TML Conference Proceeding 3: 87--95.

Leray, C., G. Nonnotte, P. Rouboud, and C. Leger. 1985. Incidence of $(n-3)$ essential fatty acid deficiency on trout reproductive processes. J. Reo. Ntr. Develop. 3: $567--581$.
Metcalfe, L.D., and A.A. Schmitz. 1961. The rapid preparation of fatty acid ester for gas chromatographic analysis. Anal. Chem. 33: 363--364.

Nurdjana, M.L. 1986. Pengaruh Ablasi Mata Unilateral terhadap Perkembangan Telur dan Embrio serta Kualitas Larva Udang Windu (Penaeus monodon Fab). Disertasi Doktor Ilmu Biologi. UGM. 97 pp.

Sargent, J.R., J.G. Bell, M.V. Bell, R.J. Henderson, and D.J. Tocher. 1993. The metabolism of phospholipids and polyunsaturated fatty acids in fish. In: B. Lahlou and P. Vitiello (Eds.) Aquaculture: Fundamental and Applied Research. Coastal and Estuarine Studies, American Geophysical Union, Washington. 43: 103$-124$.

Suwirya, K., N.A. Giri, dan M. Marzuqi. 2001. Pengaruh n3 HUFA terhadap pertumbuhan dan efisiensi pakan yuwana ikan kerapu bebek, Cromileptes altivelis. In A. Sudradjat et al. (Eds.) Teknologi Budi Daya Laut dan Pengembangan Sea Farming di Indonesia. Dept. Kelautan dan Perkanan, Jakarta. p. 201--206.

Takauchi, T., T. Arakawa, S. Satoh, and T. Watanabe. 1992. Supplemental effect of phospholipid and requirements of eicosapentaenoic acid and docosahexaenoic acid of juvenile striped jack. Nippon Suisan Gakkaishi 58(4): 707--713.

Tandler, A., M. Harel, W.M. Koven, and S. Kolkovski. 1995. Broodstock and Larvae nutrition in gilthead sea bream, Sparus aurata. New findings on its mode of involment in improving growth, survival, and swimb inflation. The Israel J. Aquaculture-Bamidgeh 47: 95$-111$.

Watanabe, T. 1983. Importance of docosahexaenoic acid in marine larval fish. J. World Aquaculture Soc. 24: 152--161.

Watanabe, T. 1988. Fish Nutrition and Mariculture JICA textbook. The general aquaculture course. $233 \mathrm{pp}$.

Watanabe, T., C. Kitajima, S. Fujita. 1993. Nutritional value of live food organism used in Japan for mass production of fish: A review. Aquaculture 155: 103-115. 